\title{
DISTRIBUTION OF ENDOCRINE-DISRUPTING PESTICIDES IN WATER AND FISH FROM THE ODER RIVER, POLAND
}

\author{
Agnieszka TOMZA-MARCINIAK ${ }^{1^{*}}$ and Agata WITCZAK $^{2}$ \\ ${ }^{1}$ Division of Animal Reproduction Biotechnology and Environmental Hygiene, \\ Faculty of Biotechnology and Animal Science, \\ ${ }^{2}$ Division of Toxicology, Faculty of Food Sciences and Fisheries, \\ West Pomeranian University of Technology, Szczecin, Poland
}

Tomza-Marciniak A., Witczak A. 2010. Distribution of endocrine-disrupting pesticides in water and fish from the Oder River, Poland. Acta Ichthyol. Piscat. 40 (1): 1-9.

Background. Organochlorine pesticides (OCPs), which act in a similar way to natural hormones, lead to disorders of the endocrine system in animals and humans (endocrine disruptors). Among food products, fish are considered to be the main source of these compounds in the human diet, posing a health risk to consumers. The aim of this study was to determine concentrations in fish and their environment of certain organochlorine pesticides in fish and their environment and to estimate daily intakes (EDI) of individual pesticides from the fish examined. Materials and Methods. Analyses aimed at detecting the pesticides (OCPs: $\alpha-, \beta-, \gamma$-HCH, heptachlor, heptachlor epoxide, aldrin, dieldrin, and endrin) included samples of water taken from the lower stretch of the Oder River and three fish species, which are commonly harvested in that area. Quantitative analyses were carried out using the Capillary Gas Chromatography/Mass Spectrometry method in a GC MSD HP 6890/5973 apparatus.

Results. The study found that concentrations of OCPs in fish gonads were significantly higher than in the muscle tissue. The dominant pesticide compound in gonads of roach and bream was $\gamma-\mathrm{HCH}$, whilst $\beta$-HCH predominated in the muscle tissues of those fishes. Endrin, on the other hand was the major pesticide in the muscle tissue of ide. Mean concentrations of OCPs in the gonads ranged from 0.385 to $0.544 \mathrm{ng} \cdot \mathrm{g}^{-1}$ wet weight (w.w.) for $\alpha-\mathrm{HCH}$, 0.745 to $0.832 \mathrm{ng} \cdot \mathrm{g}^{-1} \mathrm{w} . \mathrm{w}$. for $\gamma-\mathrm{HCH}, 0.479$ to $0.576 \mathrm{ng} \cdot \mathrm{g}^{-1} \mathrm{w}$.w. for dieldrin, and 0.381 to $0.684 \mathrm{ng} \cdot \mathrm{g}^{-1} \mathrm{w}$.w. for endrin. Concentrations of the studied compounds in the water taken from the Oder River followed the order: endrin $>\gamma-\mathrm{HCH}>\alpha-\mathrm{HCH}>$ dieldrin $>\beta-\mathrm{HCH}>$ heptachlor $\approx$ aldrin $>$ heptachlor epoxide. The highest log $\mathrm{BCF}$ was obtained for fish gonads and ranged from 1.5 (endrin) to 3.4 (heptachlor epoxide). Estimated daily intakes (EDI) varied from $0.0014 \%$ to $0.097 \%$ of the acceptable daily intake (ADI).

Conclusion. This study revealed no direct risk linked to the consumption of fish captured from the study area. However, from the ecological aspect, the accumulation of organochlorine residues in fish gonads has been considered a dangerous phenomenon, as this may result in decreased reproduction of fish and other aquatic organisms, potentially leading to their extinction.

Keywords: organochlorine pesticides, endocrine disruptors, BCF, EDI, fish

\section{INTRODUCTION}

Organochlorine pesticides (OCPs) are anthropogenic contaminants harmful to animals and humans. In the past, pesticides such as heptachlor, hexachlorocyclohexane stereoisomers $(\alpha-, \beta-, \gamma-\mathrm{HCH})$, endrin, aldrin, and dieldrin were widely used in agriculture, predominantly as insecticides, which resulted in pollution of all compartments of the environment due to high persistency of these compounds (Kannan et al. 1997, Darko et al. 2008, Hinck et al. 2008).

In many countries, mainly European ones, the production and use of the majority of these compounds has been banned for several decades, however, they are still being used in developing countries. In Poland, pesticide preparations containing dieldrin were manufactured until 1975, heptachlor only in 1966, endrin until 1972, and aldrin until 1975 (Bojakowska and Gliwicz 2005).

Pesticide use in agriculture can cause undesirable effects on human and animal health and on the natural environment. Organochlorine pesticides (OCPs), which act in a similar way to natural hormones, may lead to disorders of the endocrine system in animals and humans (endocrine disruptors) (Trudeau and Tyler 2007). Numerous studies have revealed the relationship between

\footnotetext{
* Correspondence: Dr Agnieszka Tomza-Marciniak, Katedra Biotechnologii Rozrodu Zwierząt i Higieny Środowiska, Wydział Biotechnologii i Hodowli Zwierząt, Zachodniopomorski Uniwersytet Technologiczny, ul. Doktora Judyma 6, 71-466 Szczecin, Poland, phone: +48 914496792 , fax: +48 914541642 , e-mail: atomza@wp.pl
} 
exposure to OCPs and a reduction in reproduction of animals and human (Hart et al. 2003, Henny et al. 2008). Gregoraszczuk et al. (2008) reported a stimulatory effect of environmental organic contaminants extracted from the liver oil of Atlantic cod on testosterone, 17 $\beta$-estradiol, and progesterone secretion by porcine ovarian follicular cells. Golec et al. (2003) observed morphological abnormalities in sperm as well as decreases in sperm count, percentage of viable sperm, and fecundity rate in male humans exposed to pesticides. Endocrine disrupters are being increasingly implicated in infertility, menstrual irregularities, spontaneous abortions, birth defects, endometriosis, and breast cancer (Bhatt 2000). Many studies indicate that organochlorine pesticides may damage the immune system, cause defects in the male reproductive system, low sperm concentration, and increased incidence of cancer (Porta et al. 1999, Taylor and Harrison 1999, Abell et al. 2000).

Organochlorine pesticides enter aquatic systems mainly with the surface runoff from agricultural lands and precipitation. They easily find their way from the soil surface to the atmosphere, due to their high vapour pressures, and migrate with the air currents to distant areas. That is why pollution by organochlorines occurs even in remote areas, where they have not been used for decades (Wania and Mackay 1996). Investigation of the atmosphere over Europe indicated that the highest concentrations of organochlorine pesticides are observed over the region where OCPs were produced and used in high doses and over urban areas. Higher concentration of lindane was found over south and east part of Europe (Jaward et al. 2004).

High bioaccumulation factors of these compounds in the gonads indicate a potential threat to populations of many animal species - especially aquatic ones, known to accumulate higher amounts of lipophilic organic compounds. In aquatic systems, OCPs easily join food webs, and their concentrations increase with each trophic level (Sun et al. 2006). In the case of fish, accumulation of these compounds in gonads may result in reduced reproduction potential, as well as in a decrease in fry number and developmental disorders.

Residues of organochlorine pesticides in edible parts of fish are another problem (Darko et al. 2008, Li et al. 2008). Among food products, fish are considered the main source of these compounds in human diet. Fish products sometimes contain significant amounts of these compounds that pose a health risk to consumers (Binelli and Provini 2004, Sun et al. 2006). As OCPs have the ability to induce endocrine, metabolic, and reproductive disorders, their concentrations in food products, especially in edible fish species, should be monitored. Fish have been also used in numerous studies as the most effective bioindicators in the environmental monitoring of aquatic ecosystems (Kannan et al. 1995, van der Oost et al. 2003, Hinck et al. 2008).

The Oder (Odra) is one of the longest rivers in Europe $(741.9 \mathrm{~km})$. In Widuchowa the Oder River bifurcates, with its eastern and western branches enclosing a wetland area of Międzyodrze which is one of the largest fens in Europe with unique flora and fauna (the Lower Oder
Valley Landscape Park). The pollution of the Oder River has been caused by intensive agriculture operations, big cities, industrial areas located in its catchment area, not only in Poland but also in the Czech Republic and Germany.

The aim of this study was to determine the concentrations of certain organochlorine pesticides in fish and their environment and to estimate daily intakes (EDI) of individual pesticides from the fish examined.

\section{MATERIALS AND METHODS}

This study was based on the surface water from 5 sites located in the lower stretch of the Oder River (Fig. 1), as well as gonads and muscles of roach (Rutilus rutilus), common bream (Abramis brama), and ide (Leuciscus idus) captured in that area. All samples were collected in 2003 and 2004 from 5 sites (Fig. 1). Fish were frozen $\left(-20^{\circ} \mathrm{C}\right)$ and stored in the laboratory prior to analysis. The water samples preserved by $n$-hexane were kept at $-4^{\circ} \mathrm{C}$ until extraction. Samples of water, fish gonads, and fish dorsal muscles were subjected to quantitative analysis for $\alpha-, \beta-, \gamma-\mathrm{HCH}$, heptachlor, heptachlor epoxide, aldrin, dieldrin, and endrin.

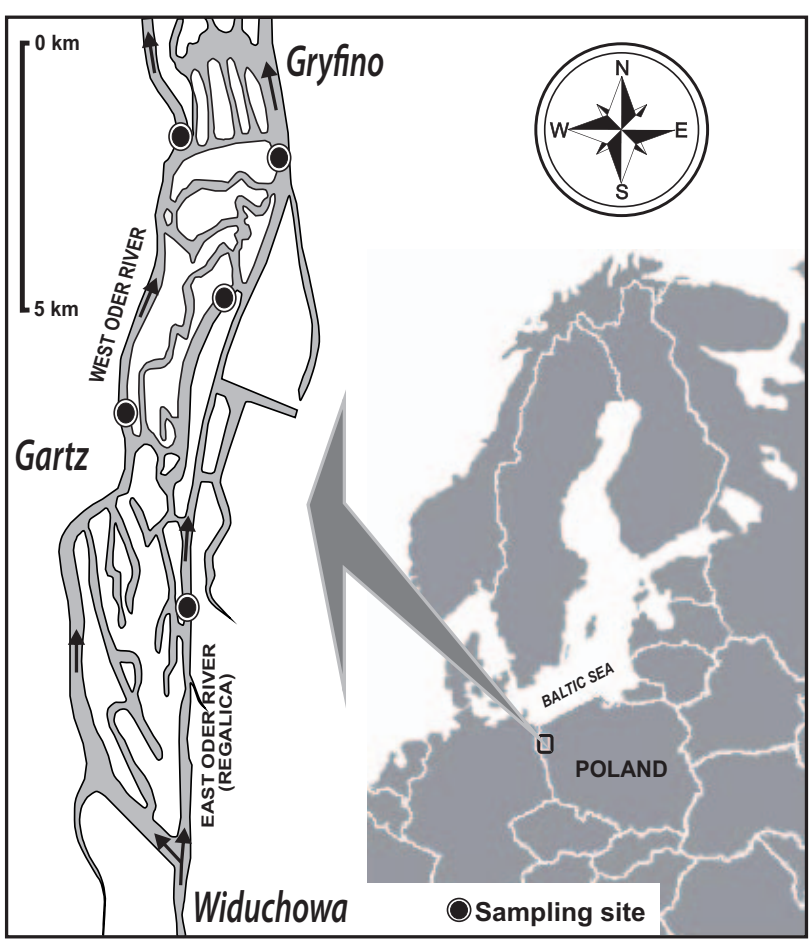

Fig. 1. Location of sample collection sites at the Międzyodrze, the lower Oder River, Poland

The study involved a total of 60 fish, 20 individuals of each species. Fish body length and weight, as well as lipid content in the gonads and muscles are presented in Table 1.

Subsamples of $30 \mathrm{~g}$ were taken for analysis. To each subsample, $50 \mu \mathrm{L}$ of internal standard (Pesticides Surrogate Spike Mix, which was an acetone solution of decachlorobiphenyl and 2,4,5,6-tetrachloro-m-xylene, SUPELCO, No 4-9151) of concentration $80 \mu \mathrm{g} \cdot \mathrm{L}^{-1}$ was added and the whole was ground in a mortar with anhydrous $\mathrm{Na}_{2} \mathrm{SO}_{4}$ until a homogenous mass was obtained. 
Mean body length and weight of fish from the lower course of the Oder River and mean lipid content in their gonads and dorsal muscles

\begin{tabular}{|c|c|c|c|c|c|c|c|c|c|}
\hline \multirow{3}{*}{ Species } & \multirow{3}{*}{$n$} & \multirow{2}{*}{\multicolumn{2}{|c|}{ Length $[\mathrm{cm}]$}} & \multirow{2}{*}{\multicolumn{2}{|c|}{ Weight $[\mathrm{g}]$}} & \multicolumn{4}{|c|}{ Lipids [\%] } \\
\hline & & & & & & & onads & & uscles \\
\hline & & mean $\pm \mathrm{SD}$ & ranoe & mean $\pm \mathrm{SD}$ & range & mean & range & mean & range \\
\hline $\begin{array}{l}\text { Roach, } \\
\text { Rutilus rutilus }\end{array}$ & 20 & $23.9 \pm 1.02$ & $20.9-25.7$ & $367.8 \pm 28.34$ & $325.25-388.25$ & 3.33 & $2.96-4.15$ & 2.02 & $1.89-2.92$ \\
\hline $\begin{array}{l}\text { Bream, } \\
\text { Abramis brama }\end{array}$ & 20 & $38.1 \pm 2.08$ & $35.2-41.3$ & $824.3 \pm 159.21$ & $793.24-1002.21$ & 3.82 & $2.88-4.74$ & 2.41 & $1.85-2.83$ \\
\hline $\begin{array}{l}\text { Ide, } \\
\text { Leuciscus idus }\end{array}$ & 20 & $36.4 \pm 2.65$ & $32.7-42.5$ & $716.6 \pm 74.81$ & 610.54-938.24 & 2.88 & $2.51-3.22$ & 2.76 & $2.14-3.46$ \\
\hline
\end{tabular}

The so prepared sample was transferred quantitatively to a conical flask with a ground glass stopper and the examined compounds were extracted together with lipids, first with an acetone : n-hexane mixture and subsequently with a n-hexane : ethyl ether mixture. The extract obtained was concentrated to $2 \mathrm{~mL}$ in a rotary vacuum evaporator at $50^{\circ} \mathrm{C}$, and quantitatively transferred with n-hexane to a dry pre-weighed $10 \mathrm{~mL}$ test tube with a ground glass stopper. Lipid content was determined gravimetrically. Next, the test tube content was redissolved in $2 \mathrm{~mL}$ of $\mathrm{n}$-hexane and purified with $6 \mathrm{~mL}$ of fuming sulphuric acid $\left(7 \% \mathrm{SO}_{3}\right.$ in concentrated $\left.\mathrm{H}_{2} \mathrm{SO}_{4}\right)$. After layers' separation, the upper (n-hexane) layer was washed with deionised water and dried over anhydrous sodium sulphate.

Water (10 L from each site) was collected to a $2.5 \mathrm{~L}$ dark glass bottle containing $300 \mathrm{~mL}$-hexane. In the laboratory, the analysed compounds were extracted with nhexane in a separator. The extract was dried over anhydrous sodium sulphate $\left(\mathrm{Na}_{2} \mathrm{SO}_{4}\right)$ and concentrated to $2 \mathrm{~mL}$ in a rotary vacuum evaporator at $50^{\circ} \mathrm{C}$. Next, the extract was purified with $6 \mathrm{~mL}$ of fuming sulphuric acid (7\% $\mathrm{SO}_{3}$ in concentrated $\mathrm{H}_{2} \mathrm{SO}_{4}$ ). After layers' separation, the upper (n-hexane) layer was quantitatively transferred to a $10-\mathrm{mL}$ test tube, washed three times with deionised water and dried over anhydrous sodium sulphate in a $8-\mathrm{mL}$ LiChrolut ${ }^{\circledR}$ glass column.

Chromatographic analysis. Earlier prepared extracts were concentrated to $0.5 \mathrm{~mL}$ in nitrogen atmosphere, and subjected to chromatographic separation in a gas-liquid system by a Capillary Gas Chromatography/Mass Spectrometry method in a GC MSD HP 6890/5973 apparatus.

Accuracy of the methods applied was checked by addition of internal standard Pesticides Surrogate Spike Mix, Supelco. Recoveries of the analysed compounds ranged within $76 \%-96 \%$ in biological material and $73 \%-91 \%$ in water. All determinations were performed in triplicate and the results were expressed as mean \pm standard deviation (SD).

Limit of quantification (LOQ) for pesticides was ranged from 0.03 to $0.04 \mathrm{ng} \cdot \mathrm{L}^{-1}$.

Bioconcentration factor. To assess the bioconcentration of organochlorine pesticides (OCPs) in the lower Oder ecosystem, bioconcentration factors (BCF) were calculated according to the following equation (Crimmins et al. 2002, van der Oost et al. 2003):

$$
\mathrm{BCF}=\frac{[\text { OCPs }] \text { organism (lipids) }}{[\text { OCPs }] \text { water }}
$$

where:

$[\text { OCPs }]_{\text {organism (lipids) }}=$ OCPs concentration in the organism (on the lipid weight basis), $[\mathrm{OCPs}]_{\text {water }}=$ OCPs concentration in water.

Statistical analysis. Statistical analysis of the results was carried out using the Statistica ${ }^{\circledR} 6.1$ software. Normality of data distribution was checked, and the significance of differences was determined by the Student's $t$-test.

\section{RESULTS}

Mean concentrations of the examined pesticides in fish gonads and muscles, and in the surface water from the Oder River, are presented in Tables 2 and 3, respectively.

The dominant pesticide compound in gonads of roach and bream was $\gamma-\mathrm{HCH}$, whilst $\beta-\mathrm{HCH}$ predominated in the muscle tissues of those fishes. Endrin, on the other hand was the major pesticide in the muscle tissue of ide. Among all the pesticides studied, only $\alpha-\mathrm{HCH}, \gamma-\mathrm{HCH}$, dieldrin, and endrin were found in all the gonad and muscle samples. In the gonads, their mean concentrations varied from $0.385 \pm 0.172 \mathrm{ng} \cdot \mathrm{g}^{-1}$ (bream) to $0.544 \pm 0.146 \mathrm{ng} \cdot \mathrm{g}^{-1}$ wet weight (w.w.) (ide) for $\alpha-\mathrm{HCH}$, from $0.745 \pm 0.236 \mathrm{ng} \cdot \mathrm{g}^{-1}$ (roach) to $0.832 \pm 0.114 \mathrm{ng} \cdot \mathrm{g}^{-1}$ w.w. (ide) for $\gamma-\mathrm{HCH}$, from $0.479 \pm 0.087 \mathrm{ng} \cdot \mathrm{g}^{-1}$ (ide) to $0.576 \pm 0.076 \mathrm{ng} \cdot \mathrm{g}^{-1}$ w.w. (bream) for dieldrin and from $0.381 \pm 0.155 \mathrm{ng} \cdot \mathrm{g}^{-1}$ (roach) to $0.684 \pm 0.216 \mathrm{ng} \cdot \mathrm{g}^{-1}$ (ide) $\mathrm{ng} \cdot \mathrm{g}^{-1}$ w.w. for endrin. In the muscles, lower concentrations were recorded, and statistical analysis revealed that the muscle levels of $\gamma$-HCH and dieldrin were significantly lower $(P \leq 0.05)$ than the gonad levels.

Heptachlor occurred only in the gonads of bream $(0.154$ $\pm 0.108 \mathrm{ng} \cdot \mathrm{g}^{-1}$ W.w. $)$ and ide $\left(0.143 \pm 0.042 \mathrm{ng} \cdot \mathrm{g}^{-1}\right.$ w.w. $)$, while heptachlor epoxide - in the gonads of roach $(0.123$ $\pm 0.088 \mathrm{ng} \cdot \mathrm{g}^{-1}$ w.w. $)$ and bream $\left(0.151 \pm 0.027 \mathrm{ng} \cdot \mathrm{g}^{-1}\right.$ w.w. $)$. None of these two pesticides was found in the muscles of fish examined in our study.

In this study, hexachlorocyclohexane isomers constituted about $50 \%$ of the total pesticide content determined in the fish organs, but only $35 \%$ of the total pesticide content determined in the water (Fig. 2). 
Table 2

Mean concentrations of organochlorine pesticides in the gonads and muscles of fish from the lower course of the Oder River

\begin{tabular}{|c|c|c|c|c|c|c|}
\hline \multirow{3}{*}{ Contaminant } & \multicolumn{6}{|c|}{ Concentration $\left[\mathrm{ng} \cdot \mathrm{g}^{-1}\right.$ w.w.] } \\
\hline & \multicolumn{2}{|c|}{ roach, Rutilus rutilus } & \multicolumn{2}{|c|}{ bream, Abramis brama } & \multicolumn{2}{|c|}{ ide, Leuciscus idus } \\
\hline & gonads & muscles & gonads & muscles & gonads & muscles \\
\hline$\alpha-\mathrm{HCH}$ & $0.385 \pm 0.172$ & $0.209 \pm 0.125$ & $0.421 \pm 0.154$ & $0.123 \pm 0.089$ & $0.544 \pm 0.146$ & $0.333 \pm 0.106$ \\
\hline$\beta-\mathrm{HCH}$ & $0.514 \pm 0.135$ & $0.439 \pm 0.123$ & $0.641 \pm 0.129$ & $0.380 \pm 0.075$ & $0.236 \pm 0.204$ & $0.131 \pm 0.096$ \\
\hline$\gamma-\mathrm{HCH}$ & $0.745 \pm 0.236$ & $0.336 \pm 0.145$ & $0.832 \pm 0.114$ & $0.318 \pm 0.042$ & $0.817 \pm 0.043$ & $0.411 \pm 0.077$ \\
\hline Heptachlor & nd & nd & $0.154 \pm 0.108$ & nd & $0.143 \pm 0.042$ & nd \\
\hline Heptachlor epoxide & $0.123 \pm 0.088$ & nd & $0.151 \pm 0.027$ & nd & nd & nd \\
\hline Aldrin & $0.149 \pm 0.025$ & nd & $0.216 \pm 0.089$ & $0.153 \pm 0.027$ & $0.359 \pm 0.083$ & $0.312 \pm 0.099$ \\
\hline Dieldrin & $0.520 \pm 0.094$ & $0.161 \pm 0.044$ & $0.576 \pm 0.076$ & $0.234 \pm 0.090$ & $0.479 \pm 0.089$ & $0.146 \pm 0.029$ \\
\hline Endrin & $0.381 \pm 0.155$ & $0.202 \pm 0.112$ & $0.594 \pm 0.240$ & $0.195 \pm 0.091$ & $0.684 \pm 0.216$ & $0.521 \pm 0.206$ \\
\hline
\end{tabular}

nd $=$ not detected.

Table 3

Organochlorine pesticide concentrations in the surface water of the lower Oder River

\begin{tabular}{lcccc}
\hline & \multicolumn{3}{c}{ Concentration $\left[\mathrm{ng} \cdot \mathrm{mL}^{-1}\right]$} & Percentage of positive samples \\
Contaminant & mean & SD & range & 100 \\
\hline$\alpha-\mathrm{HCH}$ & 0.007 & 0.004 & $0.003-0.015$ & 99 \\
$\beta-\mathrm{HCH}$ & 0.004 & 0.009 & nd -0.037 & 100 \\
$\gamma$-HCH & 0.013 & 0.018 & $0.001-0.079$ & 50 \\
Heptachlor & 0.001 & 0.002 & nd-0.007 & 15 \\
Heptachlor epoxide & $1.70 \cdot 10^{-4}$ & $3.80 \cdot 10^{-4}$ & nd-0.001 & 15 \\
Aldrin & 0.001 & 0.003 & nd- -0.013 & 50 \\
Dieldrin & 0.005 & 0.010 & nd-0.016 & 75 \\
Endrin & 0.037 & 0.069 & $0.001-0.277$ & \\
\hline
\end{tabular}

nd $=$ not detected.

Concentrations of the examined compounds in the water from the Oder River followed the order: endrin $>\gamma$-HCH $>\alpha-\mathrm{HCH}>$ dieldrin $>\beta-\mathrm{HCH}>$ heptachlor $\approx$ aldrin $>$ heptachlor epoxide. Endrin and $\gamma-\mathrm{HCH}$ constituted $54 \%$ and $19 \%$, respectively, of total pesticide content in the water. Pesticide levels in the water from the Oder River were significantly lower than in the fish. Maximum pesticide level in the water from the Oder River was $0.277 \mathrm{ng} \cdot \mathrm{mL}^{-1}$. The dominant compounds were endrin and $\gamma-\mathrm{HCH}$, the concentrations of which averaged $0.037 \pm 0.069$ $\mathrm{ng} \cdot \mathrm{mL}^{-1}$ and $0.013 \pm 0.018 \mathrm{ng} \cdot \mathrm{mL}^{-1}$, respectively.

Based on pesticide concentrations in fish organs and water samples, bioconcentration factors (log BCF) have been calculated (Fig. 3). The highest log BCFs were obtained for the fish gonads and ranged from 1.5 (endrin) to 3.4 (heptachlor epoxide). However the results did not differ significantly $(P \leq 0.05)$ from the values obtained for fish muscles, varying from 1.3 (endrin) to 3.1 (aldrin). Statistical analysis has not shown any significant differences among the $\log$ BCF values for individual compounds in the examined three fish species.

Estimated daily intakes (EDI) of individual pesticides from the fish harvested in the lower Oder River have been presented in Table 4 . The values ranged from $0.0018 \%$ to $0.097 \%$ of the acceptable daily intake (ADI) established by the FAO/WHO (Anonymous 1991a, b, 2002a).

\section{DISCUSSION}

Polychlorinated pesticides are endocrine-disrupting chemicals (ECDs). They may be harmful, as they disturb the endocrine system and reproduction in animals and humans (Fossi et al. 1999, Taylor and Harrison 1999). These changes are most visible in aquatic animals, as over 100000 endocrine-active chemicals are discharged directly into freshwater and marine ecosystems (Trudeau and Tyler 2007). Their presence in the environment poses a threat for numerous populations and reduces biodiversity (Fossi et al. 2001). Organochlorine pesticides cause major damage to aquatic life (van der Werf 1996). Pimentel et al. (1993) estimate that from 1977 to 1987 in the USA, 6-14 million fish per year were killed by pesticides.

Contaminated bottom sediments are now treated as a potential source of pollution for water ecosystems. The content of polychlorinated pesticides in fish is the consequence of the pollution of the environment in which they live. Bojakowska and Gliwicz (2005) showed that river sediments in Poland are commonly contaminated with OCPs. They were found in $97.5 \%$ of the analysed sediments from different rivers.

The dominant compound was $\beta-\mathrm{HCH}$ in roach and bream muscles and endrin in ide muscles. Although muscle concentrations of the compounds were lower than reported by others (Kannan et al. 1995, Yim et al. 2005, Sun et al. 2006, Hinck 


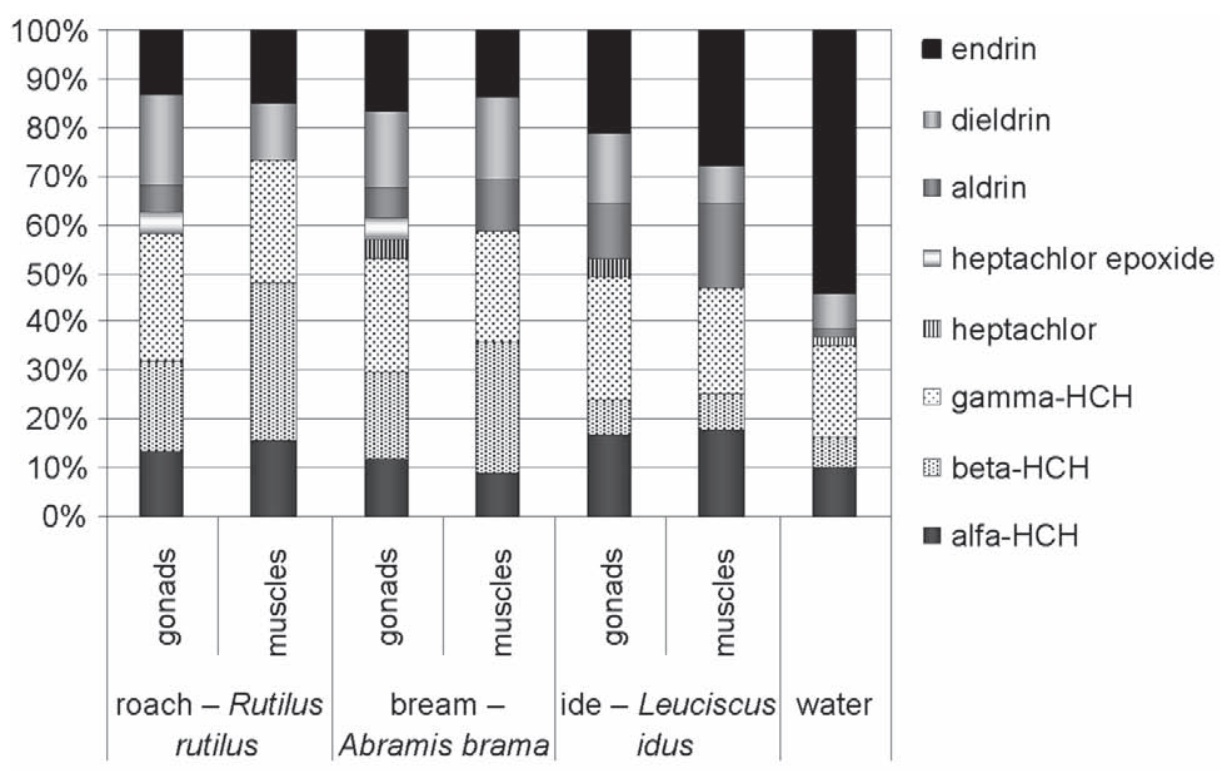

Fig. 2. Percentage share of individual pesticides in the total content of organochlorine pesticides in the surface water and in the gonads and muscles of fish from the lower course of the Oder River

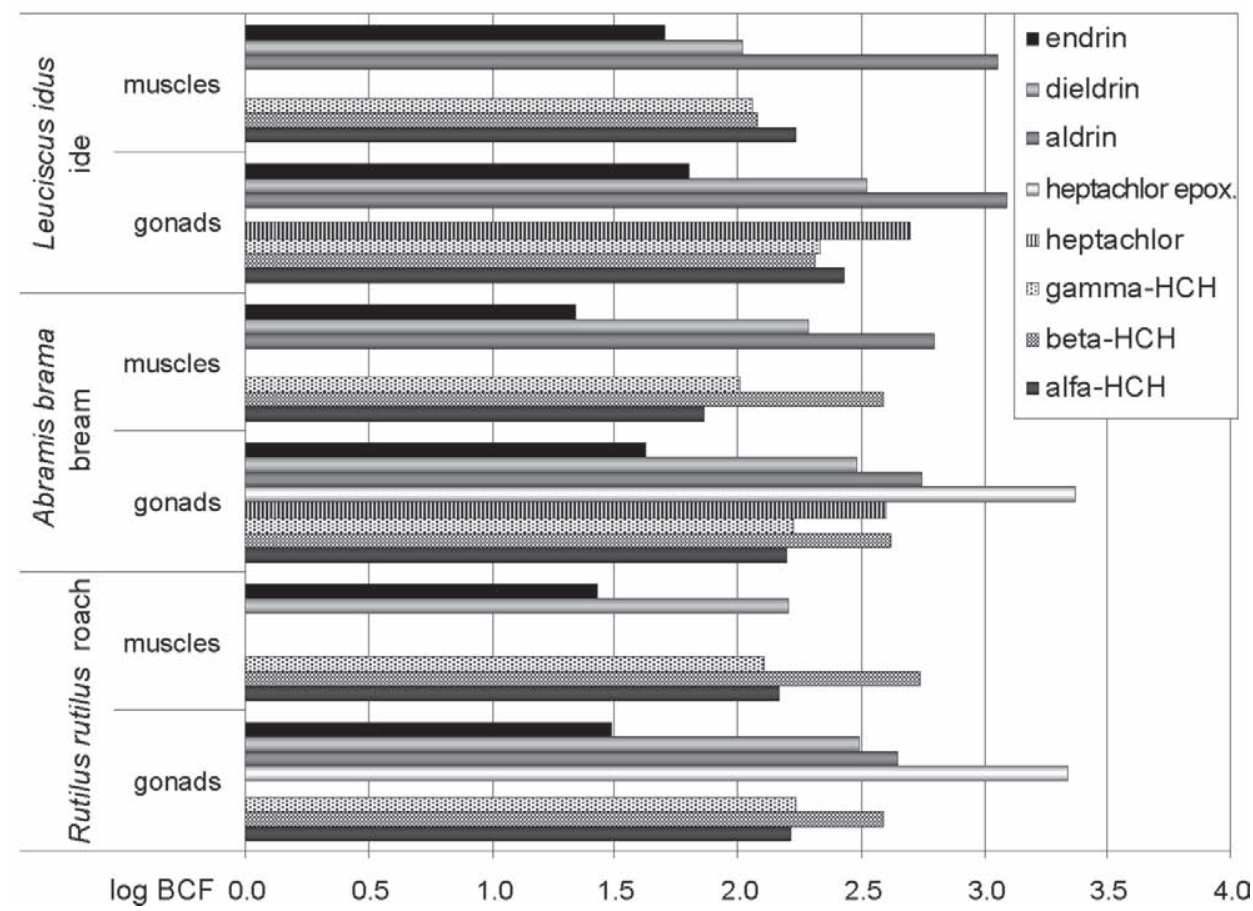

Fig. 3. Bioconcentration factors (log BCFs) of organochlorine pesticides in the gonads and muscles of fish from the lower course of the Oder River

et al. 2008), the fact that the most toxic compounds occurred in the highest concentrations seems to be alarming. Endrin is highly toxic to all animals, especially fish and other aquatic biota (Anonymous 1991b), while $\beta-\mathrm{HCH}$ is the most toxic isomer of hexachlorocyclohexane (Anonymous 2006).

The muscle levels of $\gamma-\mathrm{HCH}$ and dieldrin were significantly lower $(P \leq 0.05)$ than the gonad levels. Similar relationships for these two compounds were reported by Sapozhnikova et al. (2005). In our study, concentrations of
$\gamma-\mathrm{HCH}$ and dieldrin in fish muscles ranged from 0.318 to $0.411 \mathrm{ng} \cdot \mathrm{g}^{-1}$ w.w. and from 0.146 to $0.234 \mathrm{ng} \cdot \mathrm{g}^{-1}$ w.w., respectively. Protasowicki et al. (2007) reported higher levels of these pesticides in the muscles of roach and bream harvested from the lower Oder River in the years 1996-2000. Ciereszko and Witczak (2002) also found higher $\gamma$-HCH content in the muscles of roach and bream from the Szczecin Lagoon, which averaged $1.9 \pm 0.4$ and $2.0 \pm 0.3 \mathrm{ng} \cdot \mathrm{g}^{-1}$ w.w., respectively. 
Table 4

Estimated Daily Intakes (EDI) of organochlorine pesticides consumed by humans with the fish form the lower Oder River

\begin{tabular}{|c|c|c|c|c|}
\hline \multirow{2}{*}{ Contaminant } & \multirow{2}{*}{$\begin{array}{c}\mathrm{MCM} \\
{\left[\mathrm{ng} \cdot \mathrm{g}^{-1} \text { w.w. }\right]}\end{array}$} & \multicolumn{2}{|c|}{ EDI } & \multirow{2}{*}{$\begin{array}{l}\text { ADI } \\
{\left[\mathrm{ng} \cdot \mathrm{kg}^{-1} \text { b.w. per day }\right]}\end{array}$} \\
\hline & & {$\left[\mathrm{ng} \cdot \mathrm{kg}^{-1}\right.$ b.w. per day $]$} & {$[\%$ of $\mathrm{ADI}]$} & \\
\hline$\alpha-\mathrm{HCH}$ & 0.222 & 0.056 & - & no ADI \\
\hline$\beta-\mathrm{HCH}$ & 0.317 & 0.079 & - & no ADI \\
\hline$\gamma$-HCH & 0.355 & 0.089 & 0.0018 & $0-5000 *$ \\
\hline Heptachlor & - & - & - & $0-100 * *$ \\
\hline Heptachlor epoxide & - & - & - & no ADI \\
\hline Aldrin & 0.232 & 0.058 & 0.074 & \\
\hline Dieldrin & 0.180 & 0.045 & 0.057 & $0-100^{* *}$ \\
\hline Endrin & 0.306 & 0.077 & 0.097 & $0-200 * * *$ \\
\hline
\end{tabular}

$\mathrm{MCM}=$ Mean concentration in fish muscles $; \mathrm{EDI}=$ mean concentration in fish muscles $\left(\mathrm{ng} \cdot \mathrm{g}^{-1} \mathrm{w} . \mathrm{W}\right.$. $) \times$ fish consumption (g per day) per kg body weight $(60 \mathrm{~kg}) ; \mathrm{ADI}=$ Acceptable Daily Intake; * ADI recommended in 2002 by IMPR (Anonymous 2002); ** ADI recommended in 1991 by IMPR; as sum of aldrin and dieldrin (Anonymous 1991a); *** ADI recommended in 1970 by IMPR (Anonymous 1991a).

According to Sun et al. (2006), dieldrin residue levels in fishery products in the years 2001-2003 varied widely from 0.63 to $30.68 \mathrm{ng} \cdot \mathrm{g}^{-1}$. In contrast, Hinck et al. (2008) reported lower levels of the compound in fish from the Savannah River and Pee Dee River (USA), that averaged 3.2 and $1.73 \mathrm{ng} \cdot \mathrm{g}^{-1}$ W.W., respectively.

In our study heptachlor and heptachlor epoxide residues were found in $67 \%$ of all gonad samples. None of these two pesticides was found in the muscles of examined fish. Hinck et al. (2008) reported that heptachlor epoxide residues in the muscles of largemouth bass and common carp from the Savannah River averaged $0.26 \pm$ $0.06 \mathrm{ng} \cdot \mathrm{g}^{-1} \mathrm{w} . \mathrm{w}$. and $0.36 \pm 0.07 \mathrm{ng} \cdot \mathrm{g}^{-1}$ W.w., respectively, and in fish from the Pee Dee River its levels were nearly twice as high. Worth noticing is that intersex gonads were identified in $42 \%$ of male bass, which the authors (Hinck et al. 2008) have related to exposure to potential endocrine-disrupting compounds. At the same time, relatively high vitellogenin concentrations in male fish occurred, which could have indicated environmental exposure to estrogenic or anti-androgenic chemicals.

Our study revealed that concentrations of OCPs in fish gonads were significantly higher than in muscle tissue. Singh and Singh (2008) reported that ovary is an important organ for bioaccumulation of organochlorine pesticides. Their study indicated that during reproductive phase OCPs are transferred to the ovary from the liver, which may cause reproductive disorders. They observed a decrease in gonado-somatic index (GSI) and plasma levels of testosterone and $17 \beta$-estradiol in female fish captured from polluted rivers (Ganga and Gomti River) compared to the same species from unpolluted ponds.

The ratio of pesticide levels in fish and water equalled $100: 1$. Some organochlorine pesticides may occur in the tissues of aquatic biota at levels even a thousand times higher than in the water. For comparison, levels of these two compounds in the Qiantang River (China) varied from 0.001 to $0.026 \mathrm{ng} \cdot \mathrm{mL}^{-1}$ and from 0.010 to $0.023 \mathrm{ng} \cdot \mathrm{mL}^{-1}$, respectively (Zhou et al. 2006). Falandysz et al. (1999) reported concentrations of $\gamma-\mathrm{HCH}\left(0.012 \mathrm{ng} \cdot \mathrm{mL}^{-1}\right)$ and $\beta$-HCH $\left(0.012 \mathrm{ng} \cdot \mathrm{mL}^{-1}\right)$ in the Vistula River (Poland) similar to those detected in our study. In contrast, Darko et al. (2008) found five times higher g-HCH concentrations in the water of Bosomtwi Lake (Ghana). The same authors found no aldrin or dieldrin, while in our study these two compounds occurred in $15 \%$ and $50 \%$ of the samples, respectively (Table 3). Rovedatti et al. (2001) reported no aldrin, dieldrin, or endrin in the surface water of the Reconquista River (Argentina), but higher concentrations of $\mathrm{HCH}$ isomers and heptachlor than detected in our study. In the Jarama River (Spain), concentrations of $\mathrm{HCH}$ isomers were one order of magnitude lower than in the Oder River, but concentrations of the other pesticides were higher (Fernández et al. 2000).

Compared to the Polish and EU legal regulations for organochlorine pesticides in surface waters (Anonymous 1975, Anonymous 2002b), the OCP concentrations detected in this study in the water from the lower Oder were significantly lower than the maximum permissible limit $\left(5 \mathrm{ng} \cdot \mathrm{mL}^{-1}\right)$. Also Wolska and Namieśnik (2002) observed that the pollution of Odra River water with pesticides in general did not exceed allowable levels.

Bioconcentration factors are used for quantitative assessment of bioaccumulation, understood as a process of accumulation of a substance in fish body in proportion to its concentration in the aquatic environment (Zhou et al. 2007). In our study the values of $\log B C F$ s were from 1.5 to 3.4 for fish gonads and from 1.3 to 3.1 for fish muscles. Zhou et al. (2007) reported log BCF values higher than 3 for $\mathrm{HCH}$ isomers in the muscles of freshwater fish. Pandit et al. (2006) obtained similar results in their studies on bioaccumulation of organochlorine pesticides in the coastal marine environment of Mumbai.

Assuming that in 2007 a statistical Polish consumer ate about $5.4 \mathrm{~kg}$ of fish (Anonymous 2008), the summary daily intake of the examined pesticides from fish averaged $0.41 \mathrm{ng} \cdot \mathrm{kg}^{-1}$ body weight. EDI values obtained in this study were lower than reported in the literature. 
According to Sun et al. 2006 EDI for dieldrin was $70.45 \%-93.56 \%$ of ADI. Zhou et al. (2008) reported that estimated daily intake (EDI) of $\mathrm{HCH}$ isomers through shellfish by human was $5.83 \mathrm{ng} \cdot \mathrm{kg}^{-1}$ body wt/day. It was ten times higher than EDI obtained in our study.

\section{CONCLUSIONS}

This study revealed no direct risk linked to the consumption of fish harvested in the lower Oder River. The values obtained were significantly below the Polish maximum permissible limits. However, according to the statistical data, fish consumption in Poland increases by an average of 30 percentage points along with the consumers' age, and in the group of seniors it amounts to $7.32 \mathrm{~kg}$ per person per year. Regarding the increased health sensitivity of seniors, redistribution of toxic OCP residues from the adipose tissue may pose a threat to their health status. This may happen especially in various critical moments like disease, a sudden decrease in body weight, etc. Children are also particularly sensitive even to a few OCPs, in particular the bioaccumulation of these compounds starts in foetal life. The damage caused in this period by OCPs can influence further growth of individual children as well as the public health.

Organochlorine pesticides accumulate in the human body throughout the whole life. They are usually consumed with aquatic foodstuffs, especially with finfish. Therefore even those low concentrations of organochlorine residues in the examined fish may, in consequence, pose a health threat to humans.

Regarding ecological aspects, accumulation of organochlorine residues in the gonads is a dangerous phenomenon, as this may result in the decrease in reproduction potential of fish and other aquatic organisms, which may in turn lead to their extinction.

Because of adverse effects of OCPs on animal and human health it is necessary to monitor these compounds in the aquatic environment and in edible fish species.

\section{REFERENCES}

Abell A., Ernst E., Bonde J. 2000. Semen quality and sexual hormones in greenhouse workers. Scandinavian Journal of Work, Environment and Health 26 (6): 492-500.

Anonymous 1975. Council Directive 75/440/EEC of 16 June 1975 concerning the quality required of surface water intended for the abstraction of drinking water in the Member States. Consolidated text. Office for Official Publications of the European Communities. CONSLEG: 1975L00440$31 / 12 / 1991$.

Anonymous 1991a. Heptachlor. Evaluation for Acceptable Daily Intake. IMPR (Joint FAO/WHO Meeting on Pesticide Residues) http:/www.inchem.org/documents/jmpr/jmpmono/v91pr13.htm.

Anonymous 1991b. Endrin. Health and Safety Guide. 60. IPCS International Programme On Chemical Safety. http://www.inchem.org.

Anonymous 2002a. Pesticide residues in food. Lindan (gamma 1,2,3,4,5,6-Hexachlorocyclohexane). IMPR (Joint FAO/WHO Meeting on Pesticide Residues). http://www.inchem.org/ /documents/jmpr/jmpmono/2002pr08.htm.
Anonymous 2002b. Rozporządzenie Ministra Środowiska z 27 listopada 2002 r. w sprawie wymagań, jakim powinny odpowiadać wody powierzchniowe wykorzystywane do zaopatrzenia ludności w wodę przeznaczoną do spożycia. [Ordinance of the Minister of the Environment of 27 November 2002 on the requirements for surface waters used as public drinking water supply.] DzU 204, poz. 1728. [In Polish.]

Anonymous 2006. Assessment of lindane and other HCH isomers. United States Environmental Protection Agency (EPA). Regulation No. EPA-HQ-OPP-2006-0034-0002. http://www.epa.gov.

Anonymous 2008. Mały rocznik statystyczny Polski. [Concise statistical yearbook of Poland.] Główny Urząd Statystyczny, Warszawa.

Bhatt R.V. 2000. Environmental influence on reproductive health. International Journal of Gynecology and Obstetrics 70 (1): 69-75. DOI: 10.1016/S0020-7292(00)00221-6.

Binelli A., Provini A. 2004. Risk for human health of some POPs due to fish from Lake Iseo. Ecotoxicology and Environmental Safety 58 (1): 139-145. DOI: 10.1016/j.ecoenv.2003.09.014.

Bojakowska I., Gliwicz T. 2005. Chloroorganiczne pestycydy i polichlorowane bifenyle w osadach rzek Polski. [Chlorinated pesticides and polychlorinated biphenyls in river sediments of Poland.] Przegląd Geologiczny 53: 649-655. [In Polish.]

Ciereszko W., Witczak A. 2002. Concentration of PCBs and selected pesticides in bottom sediments, zebra mussel and in some more important fish species of the Szczecin Lagoon. Acta Ichthyologica et Piscatoria 32 (1): 35-40.

Crimmins B.S., Doelling Brown P., Kelso D.P., Foster G.D. 2002. Bioaccumulation of PCBs in aquatic biota from a tidal freshwater marsh ecosystem. Archives of Environmental Contamination and Toxicology 42: 396-404. DOI: 10.1007/s00244-001-0047-9.

Darko G., Akoto O., Oppong C. 2008. Persistent organochlorine pesticide residues in fish, sediments and water from Lake Bosomtwi, Ghana. Chemosphere 72 (1): 21-24. DOI: 10.1016/j.chemosphere.2008.02.052.

Falandysz J., Brudnowska B., Iwata H., Tanabe S. 1999. Pestycydy chloroorganiczne i polichlorowane bifenyle $\mathrm{w}$ wodzie wiślanej. [Organochlorine pesticides and polychlorinated biphenyls in water of the Vistula River.] Roczniki Państowego Zakładu Higieny 50 (2): 123-130. [In Polish.]

Fernández M., Cuesta S., Jiménez O., García M.A., Hernández L.M., Marina M. L., González M.J. 2000. Organochlorine and heavy metal residues in the water/sediment system of the Southeast Regional Park in Madrid, Spain. Chemosphere 41 (6): 801-812. DOI: 10.1016/S0045-6535(00)00004-7.

Fossi M.C., Casini S., Ancora S., Moscatelli A., Ausili A., Notarbartolo di Sciara G. 2001. Do endocrine disrupting chemicals threaten Mediterranean swordfish? Preliminary results of vitellogenin and Zona radiata proteins in Xiphias gladius. Marine Environmental Research 52 (5): 477-483. DOI: 10.1016/S0141-1136(01)00107-6.

Fossi M.C., Casini S., Marsili L. 1999. Nondestructive biomarkers of exposure to endocrine disrupting chemicals in 
endangered species of wildlife. Chemosphere 39 (8): 1273-1285. DOI: 10.1016/S0045-6535(99)00195-2.

Golec J., Hanke W., Dąbrowski S. 2003. Ryzyko zaburzeń płodności u osób zawodowo eksponowanych na pestycydy. [The risk of infertility in people occupationally exposed to pesticides.] Medycyna Pracy 54 (5): 465-472. [In Polish.]

Gregoraszczuk E.L., Milczarek K., Wójtowicz A.K., Berg V., Skaare J.U., Ropstad E. 2008. Steroid secretion following exposure of ovarian follicular cells to three different natural mixtures of persistent organic pollutants (POPs). Reproductive Toxicology 25 (1): 58-66. DOI: 10.1016/j.reprotox.2007.10.001.

Hart C.A., Nisbet I.C.T., Kennedy S.W., Hahn M.E. 2003. Gonadal feminization and halogenated environmental contaminants in common terns (Sterna hiduro): Evidence that ovotestes in male embryos do not persist to the prefledgling stage. Ecotoxicology 12 (1-4): 125-140. DOI: $10.1023 / \mathrm{A}: 1022505424074$.

Henny C.J., Grove R.A., Kaiser J.L. 2008. Osprey distribution, abundance, reproductive success and contaminant burdens along lower Columbia River, 1997/1998 versus 2004. Archives of Environmental Contamination and Toxicology 54 (3): 525-534. DOI: 10.1007/s00244-007-9041-1.

Hinck J.E., Balzer V.S., Denslow N.D., Echols K.R., Gale R.W., Wieser C., May T.W., Ellersieck M., Coyle J.J., Tillitt D.E. 2008. Chemical contaminants, health indicators, and reproductive biomarker responses in fish from rivers in the Southeastern United States. Science of Total Environment 390 (2-3): 538-557. DOI: 10.1016/j.scitotenv.2007.10.026.

Jaward F.M., Farrar N.J., Harner T., Sweetman A.J., Jones K.C. 2004. Passive air sampling of PCBs, PBDEs, and organochlorine pesticides across Europe. Environmental Science and Technology 38 (1): 34-41. DOI: $10.1021 / \mathrm{es} 034705 \mathrm{n}$.

*Kannan K., Tanabe S., Giesy J.P., Tatsukawa R. 1997. Organochlorine pesticides and polychlorinated biphenyls in foodstuffs from Asian and oceanic countries. Reviews of Environmental Contamination and Toxicology 152: 1-55.

Kannan K., Tanabe S., Tatsukawa S. 1995. Geographical distribution and accumulation features of organochlorine residues in fish in tropical Asia and Oceania. Environmental Science and Technology 29 (10): 2673-2683. DOI: 10.1021/es00010a032.

Li X., Gan Y., Yang X., Zhou J., Dai J., Xu M. 2008. Human health risk of organochlorine pesticides (OCPs) and polychlorinated biphenyls (PCBs) in edible fish from Huairou Reservoir and Gaobeidian Lake in Beijing, China. Food Chemistry 109 (2): 348-354. DOI: 10.1016/j.foodchem.2007.12.047.

Pandit G.G., Sahu S.K., Sharma S., Puranik V.D. 2006. Distribution and fate of persistent organochlorine pesticides in coastal marine environment of Mumbai. Environment International 32 (2): 240-243. DOI: 10.1016/j.envint.2005.08.018.

Pimentel D., Acquay H., Biltonen M., Rice P., Silva M., Nelson J., Lipner V., Giordano S., Horowitz A., D'Amore M. 1993. Assessment of environmental and economic costs of pesticide use. Pp. 47-84. In: Pimentel D., Lehman H. (eds.) The pesticide question: environment, economics and ethics. Routledge, Chapman and Hall, New York.
Porta M., Malats N., Jariod M., Grimalt J.O., Rifà J., Carrato A., Guarner L., Salas A., Santoiago-Silva M., Corominas J.M., Andreu M., Real F.X. 1999. Serum concentration of organochlorine compounds and K-ras mutation in exocrine pancreatic cancer. Lancet 354 (9196): 2125-2129. DOI: 10.1016/S0140-6736(99)04232-4.

Protasowicki M., Ciereszko W., Perkowska A., Ciemniak A., Bochenek I., Brucka-Jastrzębska E., Błachuta J. 2007. Metale ciężkie i chlorowane węglowodory w niektórych gatunkach ryb z rzeki Odry. [Heavy metals and polychlorinated biphenyls in certain species of fish from the Oder River.] Rocznik Ochrona Środowiska 9: 95-105. [In Polish.]

Rovedatti M.G., Castañé P.M., Topalián M.L., Salibián A. 2001. Monitoring of organochlorine and organophosphorus pesticides in the water of the Reconquista River (Buenos Aires, Argentina). Water Research 35 (14): 3457-3461. DOI: 10.1016/S0043-1354(01)00058-6.

Sapozhnikova Y., Zubcov N., Hungerford S., Roy L.A., Boicenco N., Zubcov E., Schlenk D. 2005. Evaluation of pesticides and metals in fish of the Dniester River, Moldova. Chemosphere 60 (2): 196-205.

DOI: 10.1016/j.chemosphere.2004.12.061.

Singh P., Singh V. 2008. Pesticide bioaccumulation and plasma sex steroids in fishes during breeding phase from north India. Environmental Toxicology and Pharmacology 25 (3): 342-350. DOI: 10.1016/j.etap.2007.11.003.

Sun F., Wong S.S., Li G.C., Chen S.N. 2006. A preliminary assessment of consumer's exposure to pesticide residues in fisheries products. Chemosphere 62 (4): 674-680. DOI: 10.1016/j.chemosphere.2005.04.112.

Taylor M.R., Harrison P.T.C. 1999. Ecological effect of endocrine disruption: current evidence and research priorities. Chemosphere 39 (8): 1237-1248. DOI: 10.1016/S00456535(99)00191-5.

Trudeau V., Tyler Ch. 2007. Endocrine disruption. General and Comparative Endocrinology 153 (1-3): 13-14. DOI: 10.1016/j.ygcen.2007.06.003.

van der Oost R., Beyer J., Vermeulen N.P.E. 2003. Fish bioaccumulation and biomarkers in environmental risk assessment: a review. Environmental Toxicology and Pharmacology 13 (3): 57-149.

DOI: 10.1016/S1382-6689(02)00126-6.

van der Werf H.M.G. 1996. Assessing the impact of pesticides on the environment. Agriculture, Ecosystem and Environment 60 (2-3): 81-96. DOI: $10.1016 / \mathrm{S} 0167-8809(96) 01096-1$.

Wania F., Mackay D. 1996. Tracking the distribution of persistent organic pollutants. Environmental Science and Technology/News 30 (9): 390A-396A.

Wolska L., Namieśnik J. 2002. Distribution of pollutants in the Odra River system. Part II. Organic pollutants in Odra River water. Polish Journal of Environmental Studies 11 (6): 655-661.

Yim U.H., Hong S.H., Shim W.J., Oh J.R. 2005. Levels of persistent organochlorine contaminants in fish from Korea and their potential health risk. Archives of Environmental Contamination and Toxicology 48 (3): 358-366. DOI: 10.1007/s00244-004-0085-1. 
Zhou R., Zhu L., Kong Q. 2007. Persistent chlorinated pesticides in fish species from Qiantang River in East China. Chemosphere 68 (5): 838-847. DOI: 10.1016/j.chemosphere.2007.02.021.

Zhou R., Zhu L., Kong Q. 2008. Levels and distribution of organochlorine pesticides in shellfish from Qiantang River, China. Journal of Hazardous Materials 152 (3): 1192-1200. DOI: 10.1016/j.jhazmat.2007.07.103.

Zhou R., Zhu L., Yang K., Chen Y. 2006. Distribution of organochlorine pesticides in surface water and sediments from
Qiantang River, East China. Journal of Hazardous Materials 137 (1): 68-75. DOI: 10.1016/j.jhazmat.2006.02.005.

Received: 8 April 2009 Accepted: 21 October 2009

Published electronically: 25 June 2010 